\title{
Effect of green sand mixture with dextrin additives on mechanical properties of aluminum 6351
}

\author{
Kingsley Okechukwu Ikebudu ${ }^{1, *}$, Swift Kenneth Onyegirim ${ }^{2}$ and Philip Ifchukwu Udeorah ${ }^{3}$ \\ Department of Mechanical Engineering, COOU - Chukwuemeka Odumegwu Ojukwu University, Anambra State, Nigeria.
}

Global Journal of Engineering and Technology Advances, 2021, 06(02), 131-141

Publication history: Received on 05 January 2021; revised on 10 February 2021; accepted on 12 February 2021

Article DOI: https://doi.org/10.30574/gjeta.2021.6.2.0013

\begin{abstract}
Quality of cast produced from green sand mold is been influenced by mold properties which includes green compression strength, permeability, etc. In this work the green sand used for casting of aluminum 6351 alloy specimens were made by mixing in varied percentage proportions; bentonite clay, dextrin additive and moisture content with local silica sand considering the need for most effective proportions of these mixtures to enhance green sand production of aluminum 6351 alloy products. A 3 factor, 3 level (33) design of experiment (DOE) was made for this research work using Optimal (custom) design of Design-Expert 10 software which gave 20 runs. Cylindrical specimens for green sand test were prepared according to standard per run. This was in order to study effects of bentonite clay, dextrin additive and moisture content of the green molding sand used for casting per mold this aluminum 6351 alloy. Prepared sand specimens were individually subjected to basic sand test like green sand strength and permeability test and also cast specimens per mold achieved were subjected to mechanical property test to achieve results which become the Response output of the study. These experimental results were optimized for the purpose of achieving most effective proportions of the mixtures to give effective results and from the optimal validation values, $5 \%$ water content, $12 \%$ bentonite and $8.85182 \%$ dextrin organic additive was found to be the optimized solution that gave the most effective hardness at (40.4GSS and 112PN) while 3\% water, $12 \%$ bentonite clay and $9 \%$ dextrin additive gave most effective toughness at (41.9GSS and 96.10PN).
\end{abstract}

Keywords: Dextrin; Green sand strength; Permeability; Hardness; Toughness

\section{Introduction}

The desire to produce lightweight, parts with near net shape in industry has become highly researchable topics [1]. Casting as of today is one of the most important manufacturing process widely in used. Casting is used for making intricate shapes which are difficult or too expensive to make by other methods. Casting process is vast and is carried out on almost all metals. Aluminum alloys are widely used for hundreds of compositions by all commercial casting processes including green sand, dry sand, composite mold, plaster mold, investment casting, permanent mold, etc. Aluminum alloys have excellent mechanical properties which include high strength, low density, durability, machinability and others required in manufacturing industries. These alloys are used in advanced applications due to their combinations, availability and relatively low cost as compare to competing materials. There are many process parameters affecting properties of final casted product but the additives presents in sand significantly impact final casted products. Additives are added to molding components to improve surface finish, dry strength, refractoriness, and cushioning properties [2]. Recently, additives are gaining greater application in sand mold preparation. Apart from intrinsic properties of molten metal such as fluidity, composition, segregation, etc., which affects the soundness of the cast produced, mold properties also play prominent role in determining the soundness of a casting. Other factors that may affect the heat storage capacity of sand mold includes; composition of mold material, the moisture content and

\footnotetext{
${ }^{*}$ Corresponding author: ebudu K. 0

Department of Mechanical Engineering, COOU - Chukwuemeka Odumegwu Ojukwu University, Anambra State, Nigeria. 
mold temperature. Sand casting accompanying advantage over others includes; wide range of castable sizes, flexibility to mechanization, ease of handling and cost effectiveness [3,4]. The principal constituents of molding sands are; sand grains, clay (binder), moisture and organic additives. Virtually all sand cast molds for Aluminum casting are these days green sand type mostly [5]. Green sand consists of high-quality silica sand, about 10 to 20 percent bentonite clay, 2 to 5 percent water and certain percentage of organic additive. Good molding sand always represent a compromise between conflicting factors and to obtain an acceptable compromise for the four basic requirements, the size of the sand particles, amount of bonding agent (clay), the moisture content, and organic matter percentage are all selected [6]. When molding sands are used for mold making without additives, some important characteristics may be absent in the molding sand [7]. When additives are added to molding sand, certain properties including high plasticity, temperature, metal penetration property and surface finish are improved [5]. Additives are mixed during sand preparation according to the requirement of molten metal and base sand to obtain specific characteristics in sand [6]. This study used statistical approach to check the effect of green sand mixtures with dextrin as organic additive, on mechanical properties of Aluminum 6351 alloy.

\section{Material and Methodology}

\section{$2.1 \quad$ Material}

The materials used for this research work were Aluminum (Al), Silicon powder (Si), Magnesium powder (Mg), Manganese powder (Mn), Corn flour, Dextrin powder, Bentonite clay, local Silica sand, water, wooden mold, Thermometer, Aluminum foil, Slag stick, Furnace, large metallic and plastic containers, Analogue and Electronic Scales, trowel and other casting components. They were locally sourced.

\subsection{Methodology}

Optimal (custom) DOE of Design Expert software was applied in this study to assess the influence of process parameters on quality of castings. The number of runs and design matrix depends on the number of factors and their levels. Here, number of factor is 'three' and number of levels 'three' $\left(3^{3}\right)$ as shown in Table 2.0. Also table 1 shows its design matrix.

Table 1 Independent Variables and experimental design levels.

\begin{tabular}{|l|l|l|l|l|l|l|l|}
\hline & Name & Units & Type & Levels & $\mathbf{L [ 1 ]}$ & $\mathbf{L [ 2 ]}$ & $\mathbf{L [ 3 ]}$ \\
\hline $\mathrm{A}[$ Numeric $]$ & Water & $\%$ & Discrete & 3 & 3 & 4 & 5 \\
\hline $\mathrm{B}[$ Numeric] & Bentonite & $\%$ & Discrete & 3 & 10 & 11 & 12 \\
\hline $\mathrm{C}[$ Numeric] & Dextrin & $\%$ & Discrete & 3 & 7 & 8 & 9 \\
\hline
\end{tabular}

Table 2 Design Matrix

\begin{tabular}{|l|l|l|l|l|l|l|l|}
\hline Run & $\begin{array}{l}\text { Factor 1 } \\
\text { A:Water } \\
\%\end{array}$ & $\begin{array}{l}\text { Factor 2 } \\
\text { B:Bentonite } \\
\%\end{array}$ & $\begin{array}{l}\text { Factor 3 } \\
\text { C:Dextrin } \\
\%\end{array}$ & $\begin{array}{l}\text { Response 1 } \\
\text { Green sand } \\
\text { strength } \\
\text { KN/M }\end{array}$ & $\begin{array}{l}\text { Response 2 } \\
\text { Permeability } \\
\text { PN }\end{array}$ & $\begin{array}{l}\text { Response } \\
\mathbf{3} \\
\text { Hardness } \\
\text { test } \\
\text { BHN }\end{array}$ & $\begin{array}{l}\text { Response } \\
\text { 4 } \\
\text { Impact } \\
\text { test } \\
\text { Joules }\end{array}$ \\
\hline 1 & 3 & 10 & 7 & & & \\
\hline 2 & 5 & 10 & 9 & & & & \\
\hline 3 & 3 & 11 & 8 & & & & \\
\hline 4 & 3 & 12 & 7 & & & & \\
\hline 5 & 4 & 11 & 9 & & & & \\
\hline 6 & 5 & 12 & 8 & & & & \\
\hline 7 & 4 & 12 & 7 & & & & \\
\hline 8 & 5 & 12 & 8 & & & & \\
\hline 9 & 3 & 12 & 9 & & & & \\
\hline
\end{tabular}




\begin{tabular}{|l|l|l|l|l|l|l|l|}
\hline 10 & 4 & 10 & 8 & & & & \\
\hline 11 & 5 & 12 & 7 & & & & \\
\hline 12 & 4 & 11 & 8 & & & & \\
\hline 13 & 5 & 11 & 7 & & & & \\
\hline 14 & 3 & 10 & 9 & & & & \\
\hline 15 & 5 & 10 & 9 & & & & \\
\hline 16 & 5 & 12 & 9 & 7 & & & \\
\hline 17 & 3 & 11 & 7 & 7 & & & \\
\hline 18 & 5 & 11 & 8 & & & & \\
\hline 19 & 3 & 11 & 9 & & & & \\
\hline 20 & 4 & 11 & & & & & \\
\hline
\end{tabular}

\subsubsection{Molding Mixture}

Molding mixtures used for this green sand casting experiments were silica sand, bentonite clay, dextrin additive and water content. The silica sand used was first sieved through a $2 \mathrm{~mm}$ mesh size to remove coarser particles than the finer grain sizes before sieve analysis. The samples were vibrated continuously for 15 minutes by the use of sieve shaker having mesh sizes which ranged from $1.44 \mathrm{~mm}$ to $45 \mathrm{micron}$ meter with a lid above and cover pan below them. The sieve sizes used for the experiment were classified according to the following mesh number shown in Table 3.

Table 3 Grain fineness number for sand sample (AFS).

\begin{tabular}{|l|l|l|l|l|}
\hline Mesh sizes & Weight of sand on mesh (g) & Multiplier & Product & Cumulative retained sand \\
\hline $1.44 \mathrm{~mm}$ & 6.0 & 10 & 60 & 60 \\
\hline $710 \mu \mathrm{m}$ & 7.920 & 16 & 126.72 & 186.72 \\
\hline $500 \mu \mathrm{m}$ & 9.350 & 22 & 205.70 & 392.42 \\
\hline $355 \mu \mathrm{m}$ & 11.880 & 30 & 356.40 & 748.82 \\
\hline $250 \mu \mathrm{m}$ & 13.860 & 44 & 609.84 & 1358.66 \\
\hline $125 \mu \mathrm{m}$ & 15.010 & 85 & 1275.85 & 2634.51 \\
\hline $90 \mu \mathrm{m}$ & 17.880 & 120 & 2145.60 & 4780.11 \\
\hline $45 \mu \mathrm{m}$ & 14.012 & 240 & 3362.88 & 8142.99 \\
\hline Cover pan & 4.080 & 350 & 1428.00 & 9570.99 \\
\hline Total & 99.992 & \multicolumn{5}{l}{} \\
\hline \multicolumn{5}{|r|}{ GFI: Grain fineness Index } \\
\end{tabular}

Each green sand mixture was achieved using laboratory size Muller (mixer) made by Ridsdale and Co. Ltd. with serial No.845. For each batch the mixing was up to 5 minutes before it was discharged. Bentonite clay, Dextrin additive and water content were varied according to the above DOE matrix runs in Table 2. The portions taken out from each prepared sand mixture was used to prepare standard test specimen $(5 \mathrm{~cm} \times 5 \mathrm{~cm})$ by the use of specimen cylindrical tube, a digital weighing balance and sand rammer.

\subsubsection{Green Permeability (GPN) and Green compression strength (GCS)}

$5 \mathrm{~cm} \times 5 \mathrm{~cm}$ in diameter and height test piece for each was prepared for green compression and permeability test using Ridsdale-Dietert Metric Standard Rammer. A test piece specimen of $5 \mathrm{~cm} \times 5 \mathrm{~cm}$ in diameter and height according to bentonite clay, dextrin additive and water percentage ratios mixed with silica sand per run was prepared using test cylindrical tube, digital weighing balance and Ridsdale rammer. After this the specimen was carefully stripped and removed from the tube for test using strip block. Then the $5 \mathrm{~cm} \times 5 \mathrm{~cm}$ green sand mixture was transferred to Universal Strength testing machine. Versatile equipment pvt. Ltd was used for determing Green Compression strength (GCS). For the test permeability, after the same procedure used for producing $5 \mathrm{~cm} \times 5 \mathrm{~cm}$ test piece was concluded, this time the 
test piece was not stripped out from the cylindrical tube, rather was taken while inside the tube to Ridsdale and Co. Ltd with serial No. 872 for permeability test.

Permeability number ' $\mathrm{N}$ ' is volume of air (in $\mathrm{cm}^{3}$ ) passing through a sand specimen of $1 \mathrm{~cm}^{2}$ cross-sectional area and $1 \mathrm{~cm}$ height, at a pressure difference of $1 \mathrm{gm} / \mathrm{cm}^{2}$ in one minute.

$\mathrm{N}=\mathrm{VH} / \mathrm{ATP}$

Where, $\mathrm{N}=$ permeability number

$\mathrm{V}=$ volume of air passing through the specimen in c. c.

$\mathrm{H}=$ height of specimen in $\mathrm{cm}$

$\mathrm{P}=$ pressure of air in $\mathrm{gm} / \mathrm{cm} 2$

$\mathrm{A}=$ cross-sectional area of the specimen in $\mathrm{cm} 2$

$\mathrm{T}=$ time in minutes .

\section{Results and discussion}

Table below shows the results gotten from the test conducted according to design matrix runs in chapter three.

Table 4 Design Matrix with experimental results.

\begin{tabular}{|c|c|c|c|c|c|c|c|}
\hline Run & $\begin{array}{l}\text { Factor } 1 \\
\text { A:Water } \\
\%\end{array}$ & $\begin{array}{l}\text { Factor } 2 \\
\text { B:Bentonite } \\
\%\end{array}$ & $\begin{array}{l}\text { Factor } 3 \\
\text { C:Dextrin } \\
\%\end{array}$ & $\begin{array}{l}\text { Response } 1 \\
\text { Green sand } \\
\text { strength } \\
\left(\mathrm{KN} / \mathrm{M}^{2}\right)\end{array}$ & $\begin{array}{l}\text { Response } 2 \\
\text { Permeability } \\
\text { (PN) }\end{array}$ & $\begin{array}{l}\text { Response } 3 \\
\text { Hardness } \\
\text { test } \\
\text { (BHN) } \\
\end{array}$ & $\begin{array}{l}\text { Response } 4 \\
\text { Impact test } \\
\text { (Joules) }\end{array}$ \\
\hline 1 & 3 & 10 & 7 & 57 & 86.46 & 75 & 3.3 \\
\hline 2 & 5 & 10 & 9 & 50.89 & 102.47 & 92 & 4.3 \\
\hline 3 & 3 & 11 & 8 & 50.24 & 94.66 & 72 & 4 \\
\hline 4 & 3 & 12 & 7 & 44.3 & 99.2 & 80 & 6.8 \\
\hline 5 & 4 & 11 & 9 & 47.21 & 103.5 & 83 & 4.2 \\
\hline 6 & 5 & 12 & 8 & 44.8 & 110.36 & 91 & 5 \\
\hline 7 & 4 & 12 & 7 & 48.65 & 97.86 & 80.5 & 4 \\
\hline 8 & 5 & 12 & 8 & 45 & 111.42 & 89 & 5.4 \\
\hline 9 & 3 & 12 & 9 & 43.5 & 99 & 79 & 7 \\
\hline 10 & 4 & 10 & 8 & 56.64 & 86.96 & 77 & 3.8 \\
\hline 11 & 5 & 12 & 7 & 44.2 & 108 & 89 & 5 \\
\hline 12 & 4 & 11 & 8 & 49.1 & 98.95 & 88 & 6 \\
\hline 13 & 5 & 11 & 7 & 52.7 & 101.8 & 84 & 4.5 \\
\hline 14 & 3 & 10 & 9 & 58.9 & 94.82 & 74.2 & 3.7 \\
\hline 15 & 5 & 10 & 9 & 53.76 & 106 & 87 & 3 \\
\hline 16 & 5 & 12 & 9 & 41.5 & 115.87 & 93.4 & 5 \\
\hline 17 & 3 & 11 & 7 & 50.65 & 96.84 & 75 & 4.7 \\
\hline 18 & 5 & 11 & 7 & 52.01 & 99.05 & 85 & 4.4 \\
\hline 19 & 3 & 11 & 8 & 51.05 & 93.98 & 73 & 4 \\
\hline 20 & 4 & 11 & 9 & 47.32 & 105.2 & 84 & 4.2 \\
\hline
\end{tabular}

The control sample for this study are shown in table 5 below. 
Table 5 Mechanical properties of as cast composite (control sample)

\begin{tabular}{|l|l|l|l|l|}
\hline S/n & Green sand strength (GSS) & Permeability (PN) & Hardness (BHN) & Impact Joules \\
\hline 1 & 70 & 93 & 92 & 5 \\
\hline 2 & 64 & 85 & 90 & 7 \\
\hline Average & 67 & 89 & 91 & 6 \\
\hline
\end{tabular}

The Tables (6-9) below shows ANOVA results for required models of the experiment. ANOVA is the analytical technique used to identify the importance of model(s) and its parameter(s) using student $t$ test and fishers $f$ test [8]. Determining of the significance of regression coefficient was done by Student's t test using P value standard. Generally, smaller $\mathrm{p}$ value and $\mathrm{F}$ value indicates more significant coefficient terms [9].

Tables 6, 7, 8, and 9 showed ANOVA results for green strength, permeability, hardness and impact response respectively. Also, same tables showed other adequacy measures which are 'R-square', 'adjusted R-square' and 'predicted R-square'. All these adequacies measured were in agreement logically and as well indicate significant relationships. These tables showed also statistical summaries of each model that was the output by Design Expert 10.2FI (two factorial interaction), quadratic, linear and linear models were suggested even though they have lower adjusted 'R-square' (Adj- $\mathrm{R}^{2}$ ) values than cubic models. The reason is because cubic model is aliased, which means the effects of each variable causing different signals became indistinguishable.

Coefficient of determination of 'R-square' is defined as the ratio of explained variation to total variation, and it is the measure of degree of fit. A good model fit should yield 'R-square' of not less than 0.8 [10]. Also 'R-square' value less than 0.8 is also good when 'Pred R-square' is in reasonable agreement with 'Adj R-square'. That is when their difference is less than 0.2 .

Adequate precision (Adeq Precision) measures signal to the noise ratio. And any ratio greater than 4 is desirably good. These four models have adequate precisions that are greater than 4 which indicated adequate signals. These models can be used to navigate design space.

The hardness model F-value of 30.61 from table 10 implies that the model is significant. There are only $0.01 \%$ chances that an F-value this large could actually occur due to noise. This F-value lower than 0.05 indicated that model terms are significant. In this model, bentonite clay, dextrin additive and water content are significant factors affecting hardness response on the cast product. Water with $\mathrm{P}$ value of 0.0001 indicates the most effective on hardness response.

Analysis for variance result for Hardness model showed that the main effect of these mixtures in varied percentage proportion along with three interactive effects are significant model terms. However, water has the most effect on the hardness response with dextrin having the least effect as evident in the results obtained for F value (Fisher Tests). Table 7 for the permeability model, indicated that main effect of the three variables factors and the interactive effect of parameters are significant in the order $\mathrm{AB}, \mathrm{AC}$ and $\mathrm{BC}$. Bentonite clay has the most significant effect on the permeability with the highest $\mathrm{F}$ value of 135.46 followed by water that has $\mathrm{F}$ value of 104.66 and dextrin having the least significance of $79.94 \mathrm{~F}$ value.

Table 9 showed ANOVA analysis for impact response model with main effect of the process and the interactive effects being significant here. Model F value is 5.90 and it implies significance of model. Bentonite with F value of 17.28 indicates this factor as most significant followed by water that has $1.31 \mathrm{~F}$ value and dextrin as the least with $\mathrm{F}$ value of 0.40 .

The ANOVA analysis for green sand strength response model shown in Table 6 gave model $F$ value of 30.61 with main effect of the process with also interactive being significant in its case. The model $\mathrm{F}$ value is 30.61 and it implies significant. Also there is only $0.01 \%$ chance that an F-value this much could occur due to noise. The least $\mathrm{F}$ value is 3.24 which showed water as the factor having the least effect while bentonite with $160.35 \mathrm{~F}$ value is the factor with most effective significant. 
Table 6 ANOVA analysis for Green sand strength model

\begin{tabular}{|l|l|l|l|l|l|l|}
\hline Analysis of variance table [Partial sum of squares - Type III] \\
\hline Source & $\begin{array}{l}\text { Sum of } \\
\text { Squares }\end{array}$ & $\mathbf{d f}$ & $\begin{array}{l}\text { Mean } \\
\text { Square }\end{array}$ & $\begin{array}{l}\text { F } \\
\text { Value }\end{array}$ & $\begin{array}{l}\text { p-value } \\
\text { Prob > F }\end{array}$ & \\
\hline Model & 415.41 & 6 & 69.23 & 30.61 & $<0.0001$ & Significant \\
\hline A-Water & 7.32 & 1 & 7.32 & 3.24 & 0.0952 & \\
\hline B-Bentonite & 362.72 & 1 & 362.72 & 160.35 & $<0.0001$ & \\
\hline C-Dextrin & 25.83 & 1 & 25.83 & 11.42 & 0.0049 & \\
\hline AB & 5.26 & 1 & 5.26 & 2.32 & 0.1513 & \\
\hline AC & 13.82 & 1 & 13.82 & 6.11 & 0.0280 & \\
\hline BC & 1.69 & 1 & 1.69 & 0.75 & 0.4035 & \\
\hline Residual & 29.41 & 13 & 2.26 & & & not significant \\
\hline Lack of Fit & 24.70 & 8 & 3.09 & 3.28 & 0.1034 & \\
\hline Pure Error & 4.71 & 5 & 0.94 & & & \\
\hline Cor Total & 444.81 & 19 & & & & \\
\hline
\end{tabular}

\begin{tabular}{|l|l|l|l|}
\hline Std. Dev. & 1.50 & R-Squared & 0.9339 \\
\hline Mean & 49.47 & Adj R-Squared & 0.9034 \\
\hline C.V. \% & 3.04 & Pred R-Squared & 0.7983 \\
\hline PRESS & 89.71 & Adeq Precision & 18.791 \\
\hline
\end{tabular}

Table 7 ANOVA analysis for Permeability model

\begin{tabular}{|l|l|l|l|l|l|l|}
\hline \multicolumn{2}{|l|}{ Analysis of variance table [Partial sum of squares - Type III] } \\
\hline & Sum of & & Mean & F & p-value & \\
\hline Source & Squares & df & Square & Value & Prob $>$ F & \\
\hline Model & 1065.40 & 9 & 118.38 & 41.80 & $<0.0001$ & Significant \\
\hline A-Water & 296.36 & 1 & 296.36 & 104.66 & $<0.0001$ & \\
\hline B-Bentonite & 383.60 & 1 & 383.60 & 135.46 & $<0.0001$ & \\
\hline C-Dextrin & 226.37 & 1 & 226.37 & 79.94 & $<0.0001$ & \\
\hline AB & 35.74 & 1 & 35.74 & 12.62 & 0.0052 & \\
\hline AC & 51.82 & 1 & 51.82 & 18.30 & 0.0016 & \\
\hline BC & 27.46 & 1 & 27.46 & 9.70 & 0.0110 & \\
\hline$A^{2}$ & 34.57 & 1 & 34.57 & 12.21 & 0.0058 & \\
\hline$B^{2}$ & 46.26 & 1 & 46.26 & 16.34 & 0.0024 & \\
\hline$C^{2}$ & 19.75 & 1 & 19.75 & 6.97 & 0.0247 & \\
\hline Residual & 28.32 & 10 & 2.83 & & & \\
\hline Lack of Fit & 16.07 & 5 & 3.21 & 1.31 & 0.3866 & not significant \\
\hline Pure Error & 12.25 & 5 & 2.45 & & & \\
\hline Cor Total & 1093.72 & 19 & & & & \\
\hline
\end{tabular}




\begin{tabular}{|l|l|l|l|}
\hline Std. Dev. & 1.68 & R-Squared & 0.9741 \\
\hline Mean & 100.62 & Adj R-Squared & 0.9508 \\
\hline C.V. $\%$ & 1.67 & Pred R-Squared & 0.8719 \\
\hline PRESS & 140.08 & Adeq Precision & 26.039 \\
\hline
\end{tabular}

Table 8 ANOVA analysis for Hardness model

\begin{tabular}{|l|l|l|l|l|l|l|}
\hline \multicolumn{2}{|l|}{ Analysis of variance table [Partial sum of squares - Type III] } \\
\hline Source & $\begin{array}{l}\text { Sum of } \\
\text { Squares }\end{array}$ & df & $\begin{array}{l}\text { Mean } \\
\text { Square }\end{array}$ & $\begin{array}{l}\text { F } \\
\text { Value }\end{array}$ & $\begin{array}{l}\text { p-value } \\
\text { Prob }>\text { F }\end{array}$ & \\
\hline Model & 734.02 & 3 & 244.67 & 30.61 & $<0.0001$ & significant \\
\hline A-Water & 571.45 & 1 & 571.45 & 71.50 & $<0.0001$ & \\
\hline B-Bentonite & 48.05 & 1 & 48.05 & 6.01 & 0.0261 & \\
\hline C-Dextrin & 38.87 & 1 & 38.87 & 4.86 & 0.0424 & \\
\hline Residual & 127.87 & 16 & 7.99 & & & \\
\hline Lack of Fit & 111.87 & 11 & 10.17 & 3.18 & 0.1060 & not significant \\
\hline Pure Error & 16.00 & 5 & 3.20 & & & \\
\hline Cor Total & 861.89 & 19 & & & & \\
\hline
\end{tabular}

\begin{tabular}{|l|l|l|l|}
\hline Std. Dev. & 2.83 & R-Squared & 0.8516 \\
\hline Mean & 82.56 & Adj R-Squared & 0.8238 \\
\hline C.V. $\%$ & 3.42 & Pred R-Squared & 0.7784 \\
\hline PRESS & 190.97 & Adeq Precision & 15.993 \\
\hline
\end{tabular}

Table 9 ANOVA analysis for Impact model

\begin{tabular}{|l|l|l|l|l|l|l|}
\hline \multicolumn{2}{|l|}{ Analysis of variance table [Partial sum of squares - Type III] } \\
\hline Source & $\begin{array}{l}\text { Sum of } \\
\text { Squares }\end{array}$ & $\mathbf{d f}$ & $\begin{array}{l}\text { Mean } \\
\text { Square }\end{array}$ & $\begin{array}{l}\text { F } \\
\text { Value }\end{array}$ & $\begin{array}{l}\text { p-value } \\
\text { Prob > F }\end{array}$ & \\
\hline Model & 10.99 & 3 & 3.66 & 5.90 & 0.0066 & Significant \\
\hline A-Water & 0.81 & 1 & 0.81 & 1.31 & 0.2696 & \\
\hline B-Bentonite & 10.73 & 1 & 10.73 & 17.28 & 0.0007 & \\
\hline C-Dextrin & 0.25 & 1 & 0.25 & 0.40 & 0.5380 & \\
\hline Residual & 9.94 & 16 & 0.62 & & & \\
\hline Lack of Fit & 9.01 & 11 & 0.82 & 4.40 & 0.0571 & not significant \\
\hline Pure Error & 0.93 & 5 & 0.19 & & & \\
\hline Cor Total & 20.93 & 19 & & & & \\
\hline
\end{tabular}




\begin{tabular}{|l|l|l|l|}
\hline Std. Dev. & 0.79 & R-Squared & 0.5251 \\
\hline Mean & 4.62 & Adj R-Squared & 0.4360 \\
\hline C.V. $\%$ & 17.08 & Pred R-Squared & 0.2548 \\
\hline PRESS & 15.59 & Adeq Precision & 6.985 \\
\hline
\end{tabular}

\section{Effect of Process Parameter on Responses}

\section{Optimization}

The table 10 below showed the optimization criteria used in this study for the purpose of obtaining optimal solutions of these response outputs.

Table 10 Optimization criteria used in this study.

\begin{tabular}{|c|c|c|c|c|c|}
\hline & \multirow{2}{*}{$\begin{array}{l}\text { Factors and } \\
\text { Responses }\end{array}$} & \multicolumn{2}{|l|}{ Limits } & \multirow[t]{2}{*}{ Criterion } & \multirow[t]{2}{*}{ Goal } \\
\hline & & Lower & Upper & & \\
\hline \multirow{3}{*}{ Factors } & Water & 3 & 5 & In range & In range \\
\hline & Bentonite clay & 10 & 12 & In range & In range \\
\hline & Dextrin additive & 7 & 9 & In range & In range \\
\hline \multirow{4}{*}{ Responses } & Green sand strength & 41.5 & 58.9 & In range & In Range \\
\hline & Permeability & 86.46 & 115.87 & In range & In Range \\
\hline & Hardness & 72 & 93.4 & In range & Maximize \\
\hline & Impact (toughness) & 3 & 7 & In range & Maximize \\
\hline
\end{tabular}

Below optimal solution values obtained by Design expert base on the maximizing criterion of each Response surface output showed variation in mechanical properties of aluminum 6351 alloy. From these results analysis, it is clearly seen that increase in the percentage proportion of water from $3 \%$ to $5 \%$ increasingly effected hardness and also increase in bentonite clay increasingly effected toughness and respectively they stand as the most effective to these response outputs. From Design expert's analysis, Dextrin organic additive showed its most effect on the hardness property when its proportion neared $8.5 \%$ to $8.84 \%$ and also on toughness when its proportion neared $8.99 \%$ to $9 \%$. This is mostly at a certain proportions of the other mixtures. These input factors in their various proportions showed effect on the mechanical properties of this aluminum 6351 alloy and at this level, there is need to validate the experimental results for an effective green sand casting.

Table 11 Optimal solution as obtained by Design Expert based on the criterion and Goal on green sand strength (GSS).

\begin{tabular}{|l|l|l|l|l|l|l|l|l|}
\hline Number & Water & $\begin{array}{l}\text { Bentonite } \\
\text { clay }\end{array}$ & $\begin{array}{l}\text { Dextrin } \\
\text { additive }\end{array}$ & $\begin{array}{l}\text { Green } \\
\text { sand } \\
\text { strength }\end{array}$ & Permeability & Hardness & $\begin{array}{l}\text { Impact } \\
\text { (toughness) }\end{array}$ & Desirability \\
\hline 1 & 3 & 10 & 9 & 57.727 & 94.5383 & 75.3677 & 3.9072 & 0.933 \\
\hline 2 & 3.0088 & 10 & 8.99997 & 57.7029 & 94.5248 & 75.423 & 3.90513 & 0.931 \\
\hline 3 & 3.00001 & 10 & 8.84785 & 57.6966 & 93.2615 & 75.1055 & 3.88635 & 0.931 \\
\hline
\end{tabular}


Table 12 Optimal solution as obtained by Design Expert based on the criterion and Goal on Permeability (PN)

\begin{tabular}{|l|l|l|l|l|l|l|l|l|}
\hline Number & Water & $\begin{array}{l}\text { Bentonite } \\
\text { clay }\end{array}$ & $\begin{array}{l}\text { Dextrin } \\
\text { additive }\end{array}$ & $\begin{array}{l}\text { Green sand } \\
\text { strength }\end{array}$ & Permeability & Hardness & $\begin{array}{l}\text { Impact } \\
\text { (toughness) }\end{array}$ & Desirability \\
\hline 1 & 4.98396 & 11.6954 & 8.94161 & 42.9183 & 116.258 & 91.298 & 5.11479 & 1.000 \\
\hline 2 & 4.9683 & 11.8379 & 8.97527 & 42.0342 & 116.481 & 91.5574 & 5.26481 & 1.000 \\
\hline 3 & 4.98991 & 11.9442 & 8.91936 & 41.5799 & 116.302 & 91.8205 & 5.35774 & 1.000 \\
\hline
\end{tabular}

Table 13 Optimal solution as obtained by Design Expert based on the criterion and Goal on hardness (BHN)

\begin{tabular}{|l|l|l|l|l|l|l|l|l|}
\hline Number & Water & $\begin{array}{l}\text { Bentonite } \\
\text { clay }\end{array}$ & $\begin{array}{l}\text { Dextrin } \\
\text { additive }\end{array}$ & $\begin{array}{l}\text { Green } \\
\text { sand } \\
\text { strength }\end{array}$ & Permeability & Hardness & $\begin{array}{l}\text { Impact } \\
\text { (toughness) }\end{array}$ & Desirability \\
\hline 1 & 5 & 11.9923 & 8.85488 & 41.5 & 115.87 & 91.8738 & 5.39425 & 0.929 \\
\hline 2 & 5 & 11.9972 & 8.84599 & 41.5001 & 115.79 & 91.8689 & 5.39794 & 0.928 \\
\hline 3 & 4.99999 & 11.9845 & 8.85459 & 41.5441 & 115.87 & 91.857 & 5.3865 & 0.928 \\
\hline
\end{tabular}

Table 14 Optimal solution as obtained by Design Expert based on the criterion and Goal on impact (toughness).

\begin{tabular}{|l|l|l|l|l|l|l|l|l|}
\hline Number & Water & $\begin{array}{l}\text { Bentonite } \\
\text { clay }\end{array}$ & $\begin{array}{l}\text { Dextrin } \\
\text { additive }\end{array}$ & $\begin{array}{l}\text { Green } \\
\text { sand } \\
\text { strength }\end{array}$ & Permeability & Hardness & $\begin{array}{l}\text { Impact } \\
\text { (toughness) }\end{array}$ & Desirability \\
\hline 1 & 3 & 12 & 9 & 43.2099 & 98.5253 & 79.5751 & 5.89556 & 0.724 \\
\hline 2 & 3.00895 & 11.9999 & 8.99998 & 43.2006 & 98.5517 & 79.6311 & 5.89336 & 0.723 \\
\hline 3 & 3.01845 & 12 & 8.99966 & 43.1898 & 98.5781 & 79.6904 & 5.89115 & 0.723 \\
\hline
\end{tabular}

\section{Validation of Test}

Table 15 Validation of test

\begin{tabular}{|c|c|c|c|c|c|c|c|c|}
\hline $\begin{array}{l}\text { Exp. } \\
\text { No }\end{array}$ & Water & Bentonite & Dextrin & & $\begin{array}{l}\text { Green } \\
\text { sand } \\
\text { strength } \\
\text { (GSS) }\end{array}$ & $\begin{array}{l}\text { Permeability } \\
\text { (PN) }\end{array}$ & $\begin{array}{l}\text { Hardness } \\
\text { (BHN) }\end{array}$ & $\begin{array}{l}\text { Impact } \\
\text { (toughness) } \\
\text { Joules }\end{array}$ \\
\hline \multirow[t]{2}{*}{1} & \multirow[t]{2}{*}{3.00293} & \multirow[t]{2}{*}{10} & \multirow[t]{2}{*}{8.94927} & Actual & 55.5 & 91.70 & 72 & 3.1 \\
\hline & & & & Predicted & 57.7088 & 94.1082 & 75.2987 & 3.89956 \\
\hline \multirow[t]{2}{*}{2} & \multirow[t]{2}{*}{4.98012} & \multirow[t]{2}{*}{11.84250} & \multirow[t]{2}{*}{8.94541} & Actual & 40.8 & 114.30 & 87 & 4.1 \\
\hline & & & & Predicted & 42.1775 & 116.347 & 91.5586 & 5.24578 \\
\hline \multirow[t]{2}{*}{3} & \multirow[t]{2}{*}{4.99999} & \multirow[t]{2}{*}{11.99133} & \multirow[t]{2}{*}{8.85182} & Actual & 40.4 & 112.00 & 89 & 4.4 \\
\hline & & & & Predicted & 41.5147 & 115.8433 & 91.86657 & 5.39897 \\
\hline \multirow[t]{2}{*}{4} & \multirow[t]{2}{*}{3.00913} & \multirow[t]{2}{*}{11.99997} & \multirow[t]{2}{*}{8.99988} & Actual & 41.9 & 96.10 & 75 & 4.7 \\
\hline & & & & Predicted & 43.2001 & 98.5517 & 79.6322 & 5.8934 \\
\hline
\end{tabular}

Due to the effect of various proportions of water content, bentonite clay and dextrin additives mixed with silica sand to the permeability and green strength of this molding sand, variation in white patches of the solid solution of these alloy casts are seen in their microstructure. Permeability is actually the passage of gas through the sand. This ability of air to pass through sand grains is effected by the percentage proportions of the mixtures in the molding sand. These mixture 
contents therefore affects the temperature of casting and rate of cooling which consequently affects solidification process, type of grain and the microstructure formed. In order to achieve mechanical properties in its optimal form, it is very essential for these alloying elements to be uniformly distributed. This simply means that right measures and proportions of these green sand mixtures are needed for effective green sand casting of aluminum 6351 alloy.

\section{Conclusion}

The following conclusions were drawn from the research work.

- Green molding sand mixtures which contains water (3\% - 5\%) bentonite clay (10\% - 12\%) and dextrin organic additive (7\% - 9\%) were varied successfully.

- $\quad$ Though the whole green sand mixture contents had effects in the properties of the cast, moisture content within its chosen variations has the most effect on the hardness property.

- Green sand mixture content at (water 5\%, bentonite clay 12\% and dextrin organic additive 8.85182\%) gave the highest hardness of 89 BHN from the optimal values.

- Bentonite clay factor had most effect on toughness response output, when set at (water 3\%, bentonite clay $12 \%$ and dextrin organic additive $9 \%$ ) gave 4.7 joules as the highest toughness value from the validation test.

- Dextrin organic additive with its dependant nature to other mixtures showed most effect on hardness and toughness when between $8.8 \%$ and $9 \%$. This means, the dextrin organic additive used in this study when mixed with other mixture contents at; (water $5 \%$, bentonite clay $12 \%$ and dextrin organic additive $8.85182 \%$ ), gave most effective hardness and when at (water $3 \%$, bentonite clay $12 \%$ and dextrin additive 9\%), gave most effective toughness.

- In comparison of as cast aluminum 6351 mechanical properties with properties from aluminum cast using optimized factors results has a percentage deviation of $20.72 \%$ Gss, $28.09 \%$ PN, $2.25 \%$ hardness and $27.66 \%$ toughness.

This research work gives understanding to the effect of green sand mixtures with dextrin as organic additive to mechanical properties of Aluminum 6351 alloy. Optimized parametric values of water content, bentonite clay and dextrin organic additive were obtained using statistical method. Also, enhance mechanical properties from optimized calculated values of factors gave resulted enhanced Aluminum 6351 alloy.

\section{Compliance with ethical standards}

\section{Acknowledgments}

Special gratitude to my co-authors for making this research a success.

\section{Disclosure of conflict of interest}

There are no conflict of interest for this research.

\section{References}

[1] E Olakanmi, R Cochrane, K Dalgarno. A review on selective laser sintering/melting (SLS/SLM) of aluminum alloy powders: Processing, microstructure, and properties, Progress in Materials Science. 2015; 74: 401-477.

[2] Rao. 2003; 25.

[3] Adeleke VA. Effects of Addition of Iron(Fe) Filings to Green Molding Sand on the Microstructure of Grey Cast Iron. Journal of the Brazilian Society of Mechanical Science sand Engineering, XXXII, No. 2/175. [Citation Time. 2010; (s): 5 .

[4] Alistair M Stephen, Glyn O Phillips, Peter A Williams. Food polysaccharides and their applications 2nd edition", p 92-99, CRC Press, Taylor \& Francis Group. 2006; ISBN 0-8247-5922-2.

[5] Deepak C. Green sand Management-Role \& Application of Carbonaceous Additives and Concept of Total Carbon in a Green Sand System. 68th World Foundry Congress, India. 2008; 127-132. 
[6] Paul A. Effects of the Moisture Content on the Foundry Properties of Yola Natural Sand. Leonardo Electronic Journal of Practices and Technologies. 2011; 19: 85-96.

[7] Ameen HZ, Hassan KS. Effect of the Sand Mould Additives on Some Mechanical Properties of Carbon Steel CK45 Casts. Journal of engineering. 2011; 17: 729-739.

[8] AM Howatson, PG Lund, JD Todd. Engineering Tables and Data, Chapman \& Hall. 1992.

[9] Anigbogu k, Blessing NO. New Technology and Challenges of the Blacksmithing Industry in Awka: Implication for Entrepreneurship Development. 2014.

[10] Joglekar AM, May AT. Product Excellence through Design of Experiments. Cereal foods world. 1987; 32: 857-858. 